\title{
Processing Treatments of Beniseed (Sesamum indicum Linn) on Nutrients, Anti-Nutrients Composition and Functional Properties of Flour
}

\author{
Nwamaka A. Obeta ${ }^{1,2 *}$, Chika E. Otuu1, Fabian U. Ugwuona1, Evangeline S. Peter² \\ ${ }^{1}$ Department of Food Science and Tech, College of Food Sciences and Tourism, Michael Okpara University of Agriculture, \\ Umudike, Abia State, Nigeria \\ ${ }^{2}$ Department of Food Science and Tech, Faculty of Agriculture, University of Nigeria Nsukka, Nsukka, Nigeria \\ Email: *nwamaka.obet@unn.edu.ng
}

How to cite this paper: Obeta, N.A., Otuu, C.E., Ugwuona, F.U. and Peter, E.S. (2020) Processing Treatments of Beniseed (Sesamum indicum Linn) on Nutrients, Anti-Nutrients Composition and Functional Properties of Flour. Food and Nutrition Sciences, 11, 314-325.

https://doi.org/10.4236/fns.2020.114023

Received: January 7, 2020

Accepted: April 26, 2020

Published: April 29, 2020

Copyright $\odot 2020$ by author(s) and Scientific Research Publishing Inc. This work is licensed under the Creative Commons Attribution International License (CC BY 4.0).

http://creativecommons.org/licenses/by/4.0/

(c) $\underset{\mathrm{By}}{\text { (i) Open Access }}$

\begin{abstract}
Beniseed is an important oilseed, with high oil content and nutrient composition. The effect of processing (roasting, soaking, boiling, and germination) on proximate, mineral composition, anti-nutrients and functional properties of the beniseed flour were analysed. Also the sensory properties of cookies from blends of wheat and beniseed flours were determined. The results showed that moisture, fat, crude protein, carbohydrate, ash and crude fibre contents of the flours were significantly different and ranged from $3.20 \%-4.79 \%$, $34.34 \%-50.43 \%, 15.19 \%-30.65 \%, 18.90 \%-22.16 \%, 4.54 \%-6.01 \%$ and $4.30 \%-7.59 \%$, respectively. Processing significantly $(\mathrm{p}<0.05)$ reduced the anti-nutritional factors and germination gave the highest mineral values in the beniseed flours. Water absorption capacity, oil absorption capacity, foaming stability, foaming capacity and swelling index, ranged from 1.00 $1.28,1.10-1.13,98.72-108.82,2.94-19.80$ and $1.14-1.54$ respectively. Sensory evaluation showed that $20 \%$ soaked beniseed flour substitution of wheat had no significant difference with $100 \%$ wheat cookies. Germinated sample gave a more desired nutrient composition (low fat and carbohydrate, high protein and mineral composition) but performed poorly in sensory attributes. In conclusion, beniseed gave a good flour blend with wheat in baked products, also further processing of the germinated flour to improve the appearance will give more nutritious cookies.
\end{abstract}

\section{Keywords}

Beniseed, Functional, Nutrients, Processing 


\section{Introduction}

The development of an adequate substitute for wheat will help in cost reduction of baked products. Wheat which is the cereal of choice and has a good amount of gliadin and glutenin (special protein) when processed into a dough with water produce gluten which is an elastic substance important in yeast or aerated baked products [1]. Wheat can be substituted with available, cheap and good legumes or oilseed flour. Such composite flours from legumes and oilseed have high protein content and caloric value [2].

Beniseed or sesame called Sesame indicum botanically is among the oilseeds grown worldwide. The chemical composition of sesame seed shows that it is rich in oil $(44 \%-58 \%)$, protein $(18 \%-25 \%)$ and ash $(5 \%)$ but poor in carbohydrate (13.5\%) [3]. It is a desired soup ingredient in Nigeria most especially in the north region, middle belt and some parts of the eastern states. Beniseed contains approximately $50 \%$ oil of very high quality (oleic, linoleic, palmitic, stearic in the following ranges $(35.9 \%-47 \%),(35.6 \%-47.6 \%),(8.7 \%-13.8 \%),(2.1 \%-6.4 \%)$ respectively as well as arachidic acids $(0.1 \%-0.7 \%))$. It also contains $25 \%$ protein which is rich in methionine and tryptophan [4]. Its oil is a natural salad oil requiring little or no winterization and is reported to be among the few vegetable oils used directly without refining process. Beniseed has not only nutritional benefits but also medicinal properties. Its oil contains some phytonutrients such as omega- 6 fatty acids, flavonoid phenolic anti-oxidants, vitamins and dietary fibre with potent anti-cancer and generally health promoting properties. The seed is being regarded as healthy energy food for production of liver cells and prevention of aging. It is also used to manage respiratory, cholera, diarrheal, dysentery, bowel infections and bladder disease [5].

Cereal based food products (such as biscuits and bread) are very popular in Nigeria for all age groups, especially among school children. However, one major disadvantage of such food products is poor protein source with poor nutritional quality [6]. This is so because wheat flour is the major ingredient in baked product and composed as follows: carbohydrates $(78.10 \%)$, protein $(14.70 \%)$, fat (2.10\%), minerals $(2.10 \%)$ and considerable proportions of vitamins (thiamine and vitamin-B) and minerals (zinc, iron) [7]. Beniseed contains a lot of nutrients but its usability as ingredient in some food formulations may be hindered due to the presence of anti-nutrients. These anti-nutrients mainly found in the seed hulls have adverse effect on the mineral availability in human nutrition [8]. Reducing the anti-nutrients through processing prior to consumption will aid bioavailability of those nutrients. The main objective of this work is to determine the effect of processing methods on nutrients, anti-nutrients and functional property of beniseed flour.

\section{Materials and Methods}

\subsection{Source of Materials}

Beniseed (Sesanum indicum) was purchased from Eke Imoha market Ebonyi 
State, Nigeria. The experiment was conducted in the laboratory of Food Science Technology Michael Okpara University of Agriculture Umudike, Abia State Nigeria.

\subsection{Sample Preparation}

Beniseed was sorted, washed and air dried. It was then divided into five portions of equal weight $(500 \mathrm{~g})$ and was subjected to different treatments.

A portion of beniseed was put into water $(1000 \mathrm{ml})$, dehulled by rubbing with the palms and separated by sedimentation, dried (Uniscope lab oven, model SM9023 ENGLAND) at $50^{\circ} \mathrm{C}$ and processed into flour. The sample was referred to as unprocessed beniseed flour (UBF). A second portion was soaked in distilled water at ratio of $1: 10(\mathrm{w} / \mathrm{v})$ at room temperature $\left(25^{\circ} \mathrm{C} \pm 2^{\circ} \mathrm{C}\right)$ for $12 \mathrm{~h}$ dehulled, air rested, dried and milled into flour and designated soaked beniseed flour $(\mathrm{SBF})$. The third portion was soaked in water for $2 \mathrm{~h}$ to achieve hydration and spread thinly on trays lined with wet filter paper for germination. It was partially dehulled (because it was difficult to remove all the seed coat), air rested, oven dried, milled and designated as germinated beniseed flour (GBF). A fourth portion $(500 \mathrm{~g})$ of the beniseed was soaked in water $(1: 5 \mathrm{w} / \mathrm{v})$ for $4 \mathrm{~h}$ dehulled, air rested and roasted in a hot air oven (Uniscope Lab oven, Model SM9023 ENGLAND) at $120^{\circ} \mathrm{C}$ for $1 \mathrm{~h}$ cooled, milled and designated roasted beniseed flour (RBF). The last portion was dehulled after soaking in water $(1: 5 \mathrm{w} / \mathrm{v})$ for 4 $\mathrm{h}$, boiled at $100^{\circ} \mathrm{C}$ for $30 \mathrm{~min}$ at seed to water ratio of $1: 10(\mathrm{w} / \mathrm{v})$. Consequently, the seeds were dried in an oven at $50^{\circ} \mathrm{C}$ cooled, milled and designated as boiled beniseed flour (BBF).

Wheat flour (WF) was also produced from wheat grain after sorting, washing, draining, oven drying, cooling, milling and sieving.

\subsection{Composite Flour Formulation}

Wheat and beniseed flour blends were formulated as shown in Table 1. Samples were stored at ambient temperature $\left(28^{\circ} \mathrm{C} \pm 2^{\circ} \mathrm{C}\right)$ in airtight plastic containers until required.

\subsection{Cookies Formulation}

Recipe formulation for cookies production was shown in Table 2.

\subsection{Production of Cookies}

The cookies were baked using the method of [9] with slight modification. Fat and sugar were creamed to a smooth consistency; eggs and milk were added and mixed. The dry ingredients; flour, baking powder and salt were mixed together and added to the cream followed by vanilla flavour and nutmeg, it was manually mixed (with hands in a stainless bowl) to form dough. The dough was kneaded into uniform thickness on a rolling board and cut into a uniform diameter of 50 $\mathrm{mm}$ using a cookie cutter. They were placed in greased pans and egg washed. 
Table 1. Percentage composition for wheat and beniseed composite flours.

\begin{tabular}{|c|c|c|c|c|c|c|}
\hline SAMPLE CODES & WF & SBF & GBF & RBF & $\mathrm{BBF}$ & UBF \\
\hline WF1001 & 100 & - & - & - & - & - \\
\hline WSB010 & 90 & 10 & - & - & - & - \\
\hline WSB020 & 80 & 20 & - & - & - & - \\
\hline WSB030 & 70 & 30 & - & - & - & - \\
\hline WGB030 & 90 & - & 10 & - & - & - \\
\hline WGB020 & 80 & - & 20 & - & - & - \\
\hline WGB030 & 70 & - & 30 & - & - & - \\
\hline WRB010 & 90 & - & - & 10 & - & - \\
\hline WRB020 & 80 & - & - & 20 & - & - \\
\hline WRB030 & 70 & & & 30 & & \\
\hline WBB010 & 90 & - & - & - & 10 & - \\
\hline WBB020 & 80 & & & & 20 & - \\
\hline WBB030 & 70 & & & & 30 & - \\
\hline WUB010 & 90 & - & - & - & - & 10 \\
\hline WUB020 & 80 & - & - & - & - & 20 \\
\hline WUB030 & 70 & - & - & - & - & 30 \\
\hline
\end{tabular}

Where: WF: Wheat Flour, SBF: Soaked Beniseed Flour, GBF: Germinated Beniseed Flour, RBF: Roasted Beniseed Flour, BBF: Boiled Beniseed Flour, UBF: Unprocessed Beniseed Flour, WF1001: 100\% WF; WSB010: 90\% WF: 10\% SBF; WSB020: 80\% WF: 20\% SBF; WSB030: 70\% WF: 30\% SBF; WGB010: $90 \%$ WF: 10\% GBF; WGB020: 80\% WF: 20\% GBF; WGB030: 70\% WF: 30\% GBF; WRB010: 90\% WF: $10 \%$ RBF; WRB020: 80\% WF: 20\% RBF; WRB030: 70\% WF: 30\% RBF; WBB010: 90\% WF: 10\% BBF; WBB020: $80 \%$ WF: 20\% BBF; WBB030: 70\% WF: 30\% BBF; WUB010: 90\% WF: 10\% UBF; WUB020: $80 \%$ WF: 20\% UBF; WUB030: 70\% WF: 30\% UBF.

Table 2. Recipe for cookies formulation.

\begin{tabular}{cc}
\hline Ingredients & Quantity (g) \\
\hline Composite flour (Wheat flour and Beniseed flour) & 200 \\
Margarine Fat (Assudamal Group Haano Cooking Margarine) & 72 \\
Sugar (Dangote refined granulated white sugar) & 64 \\
Powdered milk (Dano instant filled milk powder) & 74 \\
Egg & 80 \\
Baking powder (SSCL Royal Crown active baking powder) & 2 \\
Nutmeg & 2 \\
Salt & 1
\end{tabular}

The cookies were baked at $180^{\circ} \mathrm{C}$ for $20 \mathrm{~min}$. The cookies were removed and allowed to cool on a rack, after which they were packaged in low-density polyethylene bags and kept in a plastic container at ambient temperature $\left(28^{\circ} \mathrm{C} \pm\right.$ $2^{\circ} \mathrm{C}$ ) prior to evaluation. 


\section{Proximate Composition of Beniseed Flour}

Moisture, crude protein, fat, crude fibre and ash contents of beniseed flour were determined according to [10] while carbohydrate was estimated by difference [i.e. $100 \%$ - protein (\%) + fat (\%) + crude fibre (\%) +Ash (\%)].

\subsection{Determination of Minerals}

The dry ashing of the beniseed flour was carried out according to [10] as described by [11]. Calcium, Iron, Potassium, were determined using atomic absorption spectrophotometer (Buck Scientific, Model 210). Phosphorus was determined using the Spectrophotometre.

\subsection{Analysis of Anti-Nutrients: Oxalate, Phytates and Tannins}

Oxalate and phytate were determined by the [10], method. Tannins were determined by the method described by [12].

\subsection{Analysis of Functional Properties}

The procedures for determination of oil absorption capacity (OAC), water absorption capacity (WAC), swelling capacity (SC), foam capacity and stability (FC/FS) was by $[10]$.

\subsection{Determination of Sensory Properties of Cookies}

A total of 20 panelists who were familiar with the quality attributes of cookies, regular consumers of cookies and non-allergic to any cookies were recruited from staff and students of the Department of Food Science and Technology, Michael Okpara University of Agriculture Umudike, Abia State. Each panelist evaluated all the samples prepared for each treatment in one session. Panelists were instructed to evaluate appearance and colour first and then Taste each sample to evaluate flavour, texture, crispness, and general acceptability. A nine-point Hedonic scale was used with $1=$ dislike extremely, $5=$ neither like nor dislike, and $9=$ like extremely [13]. Samples were identified with three-digit code numbers and presented to panelists. The panelists were instructed to rinse their mouths with water after testing every sample.

\subsection{Statistical Analysis}

All data obtained were computed, expressed as mean \pm standard deviation, analyzed using SPSS One-way analysis of variance using ANOVA. Significant differences between the means were determined by Duncan's Multiple Range test.

\section{Result and Discussion}

The result of proximate composition of the beniseed flour sample in Table 3 showed that moisture content ranged from 3.20\% - 4.79\%. Unprocessed, soaked and boiled flour samples had no significant $(p>0.05)$ difference in moisture content while roasted and geminated had the lowest and highest significant $(\mathrm{p}<$ 
Table 3. Proximate composition of beniseed flour samples.

\begin{tabular}{cccccccc}
\hline Samples & Moisture (\%) & Fats (\%) & Protein (\%) & Fibre (\%) & Ash (\%) & Carbohydrate (\%) & Energy value (Kcals) \\
\hline UBF & $3.37^{\mathrm{bc}} \pm 0.15$ & $47.66^{\mathrm{c}} \pm 0.09$ & $19.17^{\mathrm{c}} \pm 0.03$ & $4.50^{\mathrm{b}} \pm 0.04$ & $5.30^{\mathrm{c}} \pm 0.07$ & $20.21^{\mathrm{c}} \pm 0.26$ & $586.40^{\mathrm{c}} \pm 0.92$ \\
RBF & $3.20^{\mathrm{c}} \pm 0.23$ & $49.63^{\mathrm{b}} \pm 0.03$ & $15.73^{\mathrm{d}} \pm 0.03$ & $4.56^{\mathrm{a}} \pm 0.18$ & $5.38^{\mathrm{b}} \pm 0.01$ & $21.54^{\mathrm{b}} \pm 0.21$ & $594.37^{\mathrm{b}} \pm 1.45$ \\
SBF & $3.60^{\mathrm{b}} \pm 0.20$ & $42.46^{\mathrm{b}} \pm 0.09$ & $19.65^{\mathrm{b}} \pm 0.05$ & $4.50^{\mathrm{b}} \pm 0.07$ & $4.54^{\mathrm{d}} \pm 0.06$ & $22.16^{\mathrm{a}} \pm 0.11$ & $553.35^{\mathrm{d}} \pm 1.26$ \\
BBF & $3.53^{\mathrm{bc}} \pm 0.31$ & $50.43^{\mathrm{b}} \pm 0.04$ & $15.19^{\mathrm{e}} \pm 0.03$ & $4.32^{\mathrm{c}} \pm 0.02$ & $4.62^{\mathrm{d}} \pm 0.01$ & $21.92^{\mathrm{ab}} \pm 0.35$ & $606.84^{\mathrm{a}} \pm 1.36$ \\
GBF & $4.79^{\mathrm{a}} \pm 0.20$ & $34.34^{\mathrm{b}} \pm 0.07$ & $30.65^{\mathrm{a}} \pm 0.04$ & $4.30^{\mathrm{c}} \pm 0.03$ & $6.01^{\mathrm{a}} \pm 0.01$ & $18.90^{\mathrm{d}} \pm 0.30$ & $507.26^{\mathrm{e}} \pm 0.55$ \\
\hline
\end{tabular}

*Values are mean \pm standard deviation of triplicate determinations. Means with different superscripts within the same column are significantly different ( $\mathrm{p}$ < 0.05). Keys: UBF: Unprocessed Beniseed Flour RBF: Roasted Beniseed Flour SBF: Soaked Beniseed Flour BBF: Boiled Beniseed Flour GBF: Germinated Beniseed Flour. 
may cause bloating of the intestine or constipation. Also such low fibre diets have been licked to diseases of the colon such as piles, appendicitis and cancer. The crude fibre content compared favourably with the value (4.28\%) for soya bean reported by [8].

Ash content was observed to be significantly different $(\mathrm{p}<0.05)$ among samples, the highest ash content was found in the germinated flour. This could be due to the inclusion of the sprouted roots and endogenous enzyme breaking down of complex organic compounds which releases more nutrients [18]. The energy values of the samples were significantly different $(\mathrm{p}<0.05)$, boiled beniseed contained the highest energy value. The energy values obtained in this study were similar to $563 \mathrm{kcals}$ which [19] reported for whole beniseed and compared it with groundnut ( $605 \mathrm{kcals})$, soybean (452.4 kcals), watermelon seed (576.1 kcals) among others [20]. High energy food products function as a protective agent for other nutrients in the food [21].

The results of mineral analysis of processed beniseed flour showed significant $(p<0.05)$ difference in the samples (see Table 4). The most abundant element in the samples was calcium followed by phosphorus, potassium and iron. All the minerals had highest $(\mathrm{p}<0.05)$ values in germinated beniseed flour.

Calcium as a micronutrient is important to health and bodybuilding. It has various biological functions in the body. It acts as; a messenger for almost all biological processes, makes protein stable and used for bones ossification and impulse transmission nerve. Potassium is a very useful constituent of body cells which help the muscles to function appropriately [17]. In all cases however, the values obtained for minerals in all the samples met the recommended daily requirements for both children and adults [22].

In Table 5 phytate contents of beniseed flour were affected significantly $(\mathrm{p}<$ $0.05)$ by the processing methods $(0.60 \%-0.63 \%)$ when compared with the unprocessed beniseed flour $(0.73 \%)$. The reduction in phytate level in boiled and roasted samples may not likely be as a result of destruction of compound, but may rather be its complex forming ability with protein molecules and minerals as a result of change in chemical reactivity [23]. The lowest $(\mathrm{p}<0.05)$ oxalate level was recorded in the boiled sample $(0.17 \%)$. The surprise increase of oxalate

Table 4. Result of mineral composition of beniseed flour samples (mg/100g).

\begin{tabular}{ccccc}
\hline Samples & Calcium & Phosphorus & Potassium & Iron \\
\hline UBF & $175.66^{\mathrm{c}} \pm 0.03$ & $39.79^{\mathrm{b}} \pm 0.02$ & $29.61^{\mathrm{d}} \pm 0.01$ & $1.33^{\mathrm{c}} \pm 0.03$ \\
RBF & $151.83^{\mathrm{d}} \pm 0.03$ & $35.53^{\mathrm{d}} \pm 0.02$ & $30.84^{\mathrm{c}} \pm 0.03$ & $2.02^{\mathrm{b}} \pm 0.01$ \\
SBF & $175.92^{\mathrm{b}} \pm 0.02$ & $37.63^{\mathrm{c}} \pm 0.02$ & $30.87^{\mathrm{b}} \pm 0.02$ & $2.03^{\mathrm{b}} \pm 0.02$ \\
BBF & $125.55^{\mathrm{e}} \pm 0.02$ & $35.21^{\mathrm{e}} \pm 0.02$ & $23.71^{\mathrm{e}} \pm 0.01$ & $0.92^{\mathrm{d}} \pm 0.02$ \\
GBF & $195.64^{\mathrm{a}} \pm 0.03$ & $45.10^{\mathrm{a}} \pm 0.02$ & $33.90^{\mathrm{a}} \pm 0.02$ & $2.16^{\mathrm{a}} \pm 0.02$ \\
\hline
\end{tabular}

*Values are mean \pm standard deviation of triplicate determinations. Means with different superscripts within the same column are significantly different $(\mathrm{p}<0.05)$. UBF: Unprocessed Beniseed Flour RBF: Roasted Beniseed Flour SBF: Soaked Beniseed Flour BBF: Boiled Beniseed Flour GBF: Germinated Beniseed Flour. 
Table 5. Results of anti-nutritional factors of beniseed flour samples.

\begin{tabular}{cccc}
\hline Samples & Phytate (\%) & Oxalate (\%) & Tannin (\%) \\
\hline UBF & $0.73^{\mathrm{a}} \pm 0.02$ & $0.56^{\mathrm{b}} \pm 0.03$ & $1.35^{\mathrm{b}} \pm 0.03$ \\
RBF & $0.63^{\mathrm{b}} \pm 0.02$ & $0.30^{\mathrm{c}} \pm 0.04$ & $1.59^{\mathrm{a}} \pm 0.02$ \\
SBF & $0.62^{\mathrm{c}} \pm 0.01$ & $0.17^{\mathrm{e}} \pm 0.00$ & $1.25^{\mathrm{c}} \pm 0.01$ \\
BBF & $0.60^{\mathrm{d}} \pm 0.01$ & $0.23^{\mathrm{d}} \pm 0.03$ & $1.00^{\mathrm{d}} \pm 0.01$ \\
GBF & $0.60^{\mathrm{d}} \pm 0.02$ & $0.54^{\mathrm{b}} \pm 0.04$ & $1.25^{\mathrm{c}} \pm 0.02$ \\
\hline
\end{tabular}

*Values are mean \pm standard deviation of triplicate determinations. Means with the same superscripts within the same column are not significantly different ( $p>0.05)$. UBF: Unprocessed Beniseed Flour RBF: Roasted Beniseed Flour SBF: Soaked Beniseed Flour BBF: Boiled Beniseed Flour GBF: Germinated Beniseed Flour.

in the germinated sample might be attributed to the roots and residue hulls (hulls were difficult to remove) after germination prior to drying and milling.

The reduction observed in the soaked and boiled beniseed flour may be associated with washing out of oxalate during soaking and heating into the water. Nutritive values of many food products could be affected by the concentrations of anti-nutrients. Some of the anti-nutrients like oxalic and phytates precipitate bivalent minerals (calcium, magnesium, zinc and iron) or form complexes that are insoluble and thus interfere with their utilization in the body [8]

The tannin content varied significantly $(\mathrm{p}<0.05)$ across all the samples with the highest value recorded in the roasted beniseed flour (1.59\%) and lowest value recorded in the boiled beniseed sample (1.00\%).

The result of the functional qualities of beniseed flour samples was shown in Table 6. Oil absorption capacity (OAC) values ranged from 0.97 in roasted to $1.13 \mathrm{mg} / 100 \mathrm{~g}$ in boiled beniseed flour. The low OAC of the beniseed flour samples was due to the low hydrophobic proteins in the beniseed when compared to OAC of other seeds like praseed (130.4\%) [24] and tigernut flour (107\%) [25].

Water absorption capacity (WAC) had the least value in soaked beniseed flour $(1.00 \mathrm{mg} / 100 \mathrm{~g})$ and highest in boiled beniseed flour $(1.28 \mathrm{mg} / 100 \mathrm{~g})$. The foaming capacity (FC) ranged from 2.94 in germinated to $19.80 \mathrm{mg} / 100 \mathrm{~g}$ in soaked beniseed flour. Soaking affects the morphology of the flour by increasing air spaces aiding foaming. The values for foaming capacity of beniseed flour were lower than the value for wheat (40\%) described by [26]. The amount of soluble proteins and polar and non-polar lipids in food products determines the foaming ability. Flexible protein molecules tend to reduce surface tension and so give a good foaming ability while globular proteins with highly ordered molecules are relatively hard to surface denaturation, this result in low foaming ability. Soaked sample also show highest $(\mathrm{p}<0.03)$ foaming stability $(108.82 \mathrm{~min} / \mathrm{sec})$. Swelling capacity $(\mathrm{SC})$ value varied significantly $(\mathrm{p}<0.05)$ among all samples. The highest value $(1.54 \mathrm{~g} / 100 \mathrm{~g})$ was recorded in the boiled beniseed flour and lowest $(1.14$ $\mathrm{g} / 100 \mathrm{~g}$ ) in the soaked beniseed flour.

From the results of the sensory evaluation of cookies (Table 7), there was significant difference $(\mathrm{p}<0.05)$ in appearance in some samples. The appearance of 
Table 6. Functional composition (mg/100g) of beniseed flour samples.

\begin{tabular}{cccccc}
\hline Samples & OAC & WAC & FC & FS & SC \\
\hline UBF & $1.10^{\mathrm{ab}} \pm 0.10$ & $1.23^{\mathrm{b}} \pm 0.03$ & $4.16^{\mathrm{b}} \pm 0.03$ & $100.32^{\mathrm{d}} \pm 0.55$ & $1.40^{\mathrm{b}} \pm 0.06$ \\
RBF & $0.97^{\mathrm{b}} \pm 0.02$ & $1.14^{\mathrm{c}} \pm 0.01$ & $3.92^{\mathrm{b}} \pm 0.00$ & $102.95^{\mathrm{b}} \pm 0.04$ & $1.46^{\mathrm{ab}} \pm 0.06$ \\
SBF & $0.98^{\mathrm{b}} \pm 0.011$ & $1.00^{\mathrm{d}} \pm 0.01$ & $19.80^{\mathrm{a}} \pm 0.33$ & $108.82^{\mathrm{a}} \pm 0.98$ & $1.14^{\mathrm{c}} \pm 0.03$ \\
BBF & $1.13^{\mathrm{a}} \pm 0.12$ & $1.28^{\mathrm{a}} \pm 0.03$ & $3.85^{\mathrm{b}} \pm 0.00$ & $98.72^{\mathrm{e}} \pm 0.55$ & $1.54^{\mathrm{a}} \pm 0.05$ \\
GBF & $1.10^{\mathrm{ab}} \pm 0.00$ & $1.20^{\mathrm{b}} \pm 0.03$ & $2.94^{\mathrm{c}} \pm 0.00$ & $101.63^{\mathrm{c}} \pm 0.57$ & $1.42^{\mathrm{b}} \pm 0.04$ \\
\hline
\end{tabular}

${ }^{*}$ values are mean \pm standard deviation of triplicate determinations. Means with the same superscripts within the same column are not significantly different ( $p>0.05)$. Keys: UBF: Unprocessed Beniseed Flour RBF: Roasted Beniseed Flour SBF: Soaked Beniseed Flour BBF: Boiled Beniseed Flour GBF: Germinated Beniseed Flour OAC: Oil Absorption Capacity, WAC: Water Absorption, FC: Foaming Capacity, FS: Foaming Stability and SC: swelling capacity.

Table 7. Result sensory analysis.

\begin{tabular}{|c|c|c|c|c|c|c|c|}
\hline Samples & Appearance & Colour & Flavor & Texture & Taste & Crispness & General Acceptability \\
\hline WUW001 & $7.75^{\mathrm{a}} \pm 0.96$ & $7.65^{\mathrm{a}} \pm 1.27$ & $7.40^{\mathrm{a}} \pm 1.31$ & $7.30^{\mathrm{a}} \pm 0.92$ & $7.60^{\mathrm{a}} \pm 1.10$ & $6.90^{\mathrm{a}} \pm 1.02$ & $8.15^{\mathrm{a}} \pm 0.93$ \\
\hline WSB010 & $6.75^{\mathrm{abc}} \pm 1.21$ & $6.35^{\mathrm{bc}} \pm 1.23$ & $7.05^{\mathrm{ab}} \pm 1.43$ & $6.65^{\mathrm{abc}} \pm 1.31$ & $7.30^{\mathrm{ab}} \pm 1.34$ & $6.55^{\mathrm{ab}} \pm 1.28$ & $7.80^{\mathrm{ab}} \pm 0.89$ \\
\hline WSB020 & $7.05^{\mathrm{ab}} \pm 1.67$ & $6.60^{\mathrm{bc}} \pm 1.60$ & $6.50^{\mathrm{abcd}} \pm 1.05$ & $5.90^{\text {cde }} \pm 1.68$ & $6.35^{\text {bcde }} \pm 1.14$ & $5.40^{\text {bcdef }} \pm 1.43$ & $7.10^{\mathrm{bcd}} \pm 1.29$ \\
\hline WSB030 & $4.85^{\mathrm{ef}} \pm 1.76$ & $4.90^{\mathrm{de}} \pm 1.80$ & $5.95^{\text {cde }} \pm 1.36$ & $5.45^{\mathrm{def}} \pm 1.47$ & $5.35^{\mathrm{efg}} \pm 1.84$ & $6.05^{\mathrm{abcd}} \pm 1.79$ & $6.05^{\mathrm{def}} \pm 1.36$ \\
\hline WGB020 & $4.35^{\mathrm{f}} \pm 1.42$ & $4.45^{\mathrm{e}} \pm 1.67$ & $4.45^{\mathrm{g}} \pm 1.79$ & $4.60^{\mathrm{f}} \pm 1.39$ & $3.55^{\mathrm{i}} \pm 1.70$ & $4.35^{\mathrm{f}} \pm 1.35$ & $4.55^{\mathrm{g}} \pm 1.90$ \\
\hline WSB030 & $4.85^{\mathrm{ef}} \pm 1.76$ & $4.90^{\mathrm{de}} \pm 1.80$ & $5.95^{\text {cde }} \pm 1.36$ & $5.45^{\mathrm{def}} \pm 1.47$ & $5.35^{\mathrm{efg}} \pm 1.84$ & $6.05^{\mathrm{abcd}} \pm 1.79$ & $5.55^{\mathrm{f}} \pm 2.06$ \\
\hline WGB010 & $5.65^{\mathrm{de}} \pm 1.63$ & $5.90^{\mathrm{bcd}} \pm 1.29$ & $5.30^{\operatorname{defg}} \pm 1.34$ & $5.45^{\mathrm{def}} \pm 1.47$ & $4.55^{\text {ghi }} \pm 1.93$ & $4.85^{\mathrm{ef}} \pm 1.79$ & $6.05^{\mathrm{def}} \pm 1.36$ \\
\hline WGB020 & $4.35^{\mathrm{f}} \pm 1.42$ & $4.45^{\mathrm{e}} \pm 1.67$ & $4.45^{\mathrm{g}} \pm 1.79$ & $4.60^{\mathrm{f}} \pm 1.39$ & $3.55^{\mathrm{i}} \pm 1.70$ & $4.35^{\mathrm{f}} \pm 1.35$ & $4.55^{\mathrm{g}} \pm 1.90$ \\
\hline WGB030 & $4.80^{\mathrm{ef}} \pm 1.82$ & $4.90^{\mathrm{de}} \pm 1.94$ & $4.65^{\mathrm{fg}} \pm 1.69$ & $5.20^{\mathrm{ef}} \pm 2.01$ & $3.95^{\mathrm{hi}} \pm 2.21$ & $5.00^{\mathrm{def}} \pm 1.69$ & $5.55^{\mathrm{f}} \pm 2.06$ \\
\hline WRB010 & $6.30^{\mathrm{bcd}} \pm 1.22$ & $5.95^{\mathrm{bcd}} \pm 1.85$ & $5.35^{\mathrm{defg}} \pm 1.66$ & $5.25^{\mathrm{ef}} \pm 1.59$ & $5.00^{\mathrm{fgh}} \pm 2.25$ & $5.35^{\text {cdef }} \pm 1.84$ & $5.90^{\mathrm{ef}} \pm 1.97$ \\
\hline WRB020 & $6.45^{\mathrm{bcd}} \pm 1.32$ & $5.80^{\mathrm{bcd}} \pm 1.54$ & $6.20^{\mathrm{bcd}} \pm 1.82$ & $6.50^{\mathrm{abcd}} \pm 1.40$ & $6.60^{\mathrm{abcd}} \pm 1.98$ & $6.35^{\mathrm{abc}} \pm 1.98$ & $7.77 .10^{\mathrm{bcd}} \pm 1.74$ \\
\hline WRB030 & $6.65^{\mathrm{bcd}} \pm 1.60$ & $6.15^{\mathrm{bc}} \pm 1.39$ & $6.15^{\mathrm{bcd}} \pm 1.79$ & $6.15^{\text {bcde }} \pm 1.46$ & $6.25^{\text {bcde }} \pm 1.65$ & $6.40^{\mathrm{abc}} \pm 1.43$ & $6.75^{\text {cde }} \pm 1.37$ \\
\hline WBB010 & $6.90^{\mathrm{abc}} \pm 1.55$ & $6.85^{\mathrm{ab}} \pm 1.60$ & $6.25^{\mathrm{bcd}} \pm 1.52$ & $5.95^{\text {cde }} \pm 1.36$ & $6.20^{\text {bcdef }} \pm 1.64$ & $6.00^{\mathrm{abcde}} \pm 1.26$ & $77.05^{\mathrm{bcd}} \pm 1.19$ \\
\hline WBB020 & $6.70^{\mathrm{bcd}} \pm 1.42$ & $6.55^{\mathrm{bc}} \pm 1.32$ & $5.85^{\text {cde }} \pm 1.31$ & $5.75^{\text {cde }} \pm 1.65$ & $6.05^{\text {cdef }} \pm 1.64$ & $5.45^{\text {bcdef }} \pm 1.70$ & $6.50^{\mathrm{def}} \pm 1.32$ \\
\hline WBB030 & $5.90^{\mathrm{cd}} \pm 1.77$ & $6.05^{\mathrm{bc}} \pm 1.50$ & $6.00^{\text {bcde }} \pm 1.65$ & $5.40^{\mathrm{def}} \pm 1.79$ & $5.40^{\operatorname{defg}} \pm 1.67$ & $5.30^{\text {cdef }} \pm 1.78$ & $6.10^{\mathrm{def}} \pm 1.48$ \\
\hline WUB010 & $6.80^{\mathrm{abc}} \pm 1.24$ & $6.70^{\mathrm{abc}} \pm 1.30$ & $7.05^{\mathrm{ab}} \pm 1.10$ & $7.05^{\mathrm{ab}} \pm 1.05$ & $6.95^{\mathrm{abc}} \pm 1.23$ & $6.80^{\mathrm{abc}} \pm 1.40$ & $7.55^{\mathrm{abc}} \pm 1.19$ \\
\hline WUB020 & $6.20^{\mathrm{bcd}} \pm 1.01$ & $5.80^{\mathrm{bcd}} \pm 1.51$ & $5.65^{\text {cdef }} \pm 1.50$ & $5.55^{\mathrm{def}} \pm 1.39$ & $5.95^{\text {cdef }} \pm 1.70$ & $6.00^{\mathrm{abcde}} \pm 1.97$ & $6.40^{\mathrm{def}} \pm 1.64$ \\
\hline WUB030 & $5.65^{\mathrm{de}} \pm 1.57$ & $5.65^{\mathrm{cd}} \pm 1.57$ & $5.05^{\mathrm{efg}} \pm 1.64$ & $6.05^{\text {bcde }} \pm 1.64$ & $5.30^{\text {efg }} \pm 1.63$ & $5.50^{\text {bcdef }} \pm 1.85$ & $6.20^{\mathrm{def}} \pm 1.40$ \\
\hline
\end{tabular}

WF1001: 100\% WF; WSB010: 90\% WF: 10\% SBF; WSB020: 80\% WF: 20\% SBF; WSB030: 70\% WF: 30\% SBF; WGB010: 90\% WF: 10\% GBF; WGB020: 80\% WF: 20\% GBF; WGB030: 70\% WF: 30\% GBF; WRB010: 90\% WF: 10\% RBF; WRB020: 80\% WF: 20\% RBF; WRB030: 70\% WF: 30\% RBF; WBB010: 90\% WF: 10\% BBF; WBB020: 80\% WF: 20\% BBF; WBB030: 70\% WF: 30\% BBF; WUB010: 90\% WF: 10\% UBF; WUB020: 80\% WF: 20\% UBF; WUB030: 70\% WF: 30\% $\mathrm{UBF}$.

cookies baked with $10 \%$ and $20 \%$ soaked, $10 \%$ boiled, $10 \%$ unprocessed beniseed flours substituted with wheat were not significantly different $(\mathrm{p}>0.05)$ from $100 \%$ wheat cookies. The cookies substituted with $20 \%$ germinated beniseed flour was least preferred among all samples. 
The colour of the $100 \%$ wheat flour cookie was most preferred but not significantly different $(\mathrm{p}>0.05)$ with the cookies substituted with $10 \%$ boiled and $10 \%$ unprocessed beniseed flour. The $10 \%$ soaked, $20 \%$ and $30 \%$ germinated substituted beniseed flour cookies were least preferred in terms of colour. There were significant differences $(\mathrm{p}<0.05)$ among the samples. The cookies substituted with $10 \%$ and $20 \%$ soaked, $20 \%$ and $30 \%$ roasted, $10 \%$ and $30 \%$ boiled and $10 \%$ unprocessed beniseed flour were more preferred in terms of flavor to the other samples. For texture, there was no significant difference $(p>0.05)$ between the $100 \%$ wheat flour cookie and the cookies substituted with $10 \%$ soaked, $20 \%$ roasted and $10 \%$ unprocessed beniseed flour. However, the cookies substituted with germinated beniseed flour sample were least preferred among all. Taste showed slight differences $(\mathrm{p}<0.05)$ between the cookies, with obvious significant difference $(\mathrm{p}<0.05)$ observed in the beniseed germinated flour substituted wheat cookies.

In terms of crispness, all substituted beniseed flour cookies were quite comparable with the $100 \%$ wheat flour cookies except for the cookies substituted with germinated beniseed flour. General acceptability showed that there was no significant difference $(\mathrm{p}>0.05)$ between the $100 \%$ wheat flour cookies and cookies from $10 \%$ soaked and $10 \%$ unprocessed substituted beniseed flour. The poor performance of the cookies substituted with beniseed flour especially the germinated samples (with residue seed coat) could be attributed to the bitter taste of some inherent compounds found in beniseed flour particularly at high temperature.

\section{Conclusion}

This study revealed that processing had significant effect on the nutrients, anti-nutrients and functional properties of beniseed flour samples. Germinated flour sample had highest protein and ash contents, lowest fat and carbohydrate values with increased mineral and reduced anti-nutrients, making it a more preferred flour sample. From the study beniseed can substitute wheat in many other food products to improve food security and reduce malnutrition especially in Nigeria where there are a lot of vulnerable groups.

\section{Conflicts of Interest}

The authors declare no conflicts of interest regarding the publication of this paper.

\section{References}

[1] Obeta, N.A., Ugwuona, F.U. and Ogbonna, G.A. (2016) Quality Characteristic of Instant Noodles Produced from Blends of Cocoyam and Wheat Flours. Annual Conference of NIFST Proceedings, Kano, 24-26 October 2016, 33-34.

[2] Igbabul, B.D., Iorliam, B.M. and Umana, E.N. (2014) Physicochemical and Sensory Properties of Cookies Produced from Composite Flours of Wheat, Cocoyam and African Yam Beans. Journal of Food Research, 2, 109-115. 
https://doi.org/10.5539/jfr.v4n2p150

[3] Borchani, C., Besbes, S., Blecker, C.H. and Attia, H. (2010) Chemical Characteristics and Oxidative Stability of Sesame Seed, Sesame Paste, and Olive Oils. Journal of Agriculture, Science and Technology, 12, 585-596.

[4] Adeniyan, O.O., Ibukun, E.O., Ogunbolude, Y. and Eseigbe, M.I. (2013) Effect of Boiling on the Nutritional Composition and Antioxidant Properties of Beniseed (Sesamum indicum L.). Food Science and Quality Management, 11, 40-48. http://www.iiste.org

[5] Henry, P., Edward, M.J., Essien, N.A. and Emmanuel, I.C. (2016) Nutritional Evaluation of Breadfruit and Beniseed Composite Flours. American Journal of Food Science and Technology, 4, 182-187. https://doi.org/10.15406/mojfpt.2016.02.00056

[6] Olagunju, A.I. and Ifesan, B.O.T. (2013) Nutritional Composition and Acceptability of Cookies Made from Wheat Flour and Germinated Sesame (Sesamum indicum) Flour Blends. British Journal of Applied Sciences and Technology, 3, 702-713. https://doi.org/10.9734/BJAST/2013/3547

[7] Topping, D. (2007) Cereal Complex Carbohydrates and Their Contribution to Human Health. Journal of Cereal Science, 46, 220-229.

https://doi.org/10.1016/j.jcs.2007.06.004

[8] Adegunwa, M.O., Adebowale, A.A. and Solano, E.O. (2012) Effects of Thermal Processing on the Biochemical Composition, Anti-Nutritional Factors and Functional Properties of Beniseed (Sesamum indicum) Flour. American Journal of Biochemistry and Molecular Biology, 2, 175-182. https://doi.org/10.3923/ajbmb.2012.175.182

[9] Okpala, L., Okoli, E. and Udensi, E. (2012) Physicochemical and Sensory Properties of Cookies Made from Blends of Germinated Pigeon Pea, Fermented Sorghum and Cocoyam Flours. Food Science and Nutrition, 1, 8-14. https://doi.org/10.1002/fsn3.2

[10] AOAC (2010) Official Methods of Analysis. 18th Edition, Revision 3. Association of Official Analytical Chemists, Washington DC.

[11] Arisa, N.U., Adelekan, A.O., Alamu, A.E. and Ogunfowora, E.J. (2013) The Effect of Pre-Treatment of Plantain (Musa parasidiaca) Flour on the Pasting and Sensory Characteristics of Biscuit. International Journal of Food and Nutrition Science, 2, 10-23.

[12] Kirk, R.S. and Sawyer, R. (1991) Pearson's Composition and Chemical Analysis of Foods. 9th Edition, Longman Scientific \& Technical, Essex.

[13] Iwe, M.O. (2010) Handbook of Sensory Methods and Analysis. 2nd Edition, Rojoint Communication Services Ltd., Enugu.

[14] Makinde, F.M. and Akinoso, R. (2013) Nutrient Composition and Effect of Processing Treatments on Anti-Nutritional Factors of Nigerian Sesame (Sesamum indicum Lin) Cultivars. International Food Research Journal, 20, 2293-2300.

[15] Onwuka, C.F., Ikewuchi, C.C., Ikewuchi, C.J. and Ayalogu, O.E. (2008) Investigation on the Effect of Germination on the Proximate Composition of African Yam Bean (Sphenostylis stenocarpa Hochst ex A Rich) and Fluted Pumpkin (Telferia occidentalis). Journal of Applied Science and Environmental Management, 13, 59-61. https://doi.org/10.4314/jasem.v13i2.55310

[16] Ojiako, O.A., Igwe, C.U., Agha, N.C., Ogbuji, C.A. and Onwuliri, V.A. (2010) Protien and Amino Acid Composition of Aphenostylis stenocarpa, Sesamum indicum, Monodora mytistica and Afzelia africana Seeds from Nigeria. Pakistan Journal of Nutrition, 9, 368-372. https://doi.org/10.3923/pjn.2010.368.372 
[17] Obeta, N.A. (2015) Effect of Moist Heating and Drying Processing on the Proximate and Phytochemical Composition of Vernonia amygdalina and Gongronema latifolium Leaves. Agricultural Science Research Journal, 5, 153-165.

http://resjournals.com/journals/agricultural-science-research-journalshtml

[18] Chikwendu, N.J. (2003) The Effect of Germination on the Chemical Composition and Microbial Quality of Ground Bean (Kerstingiella geocarpa) Flours. Nigerian Journal of Nutritional Science, 24, 17-22.

[19] Weiss, E.A. (1983) Oilseed Crops. Blackwell Longman Group Ltd., Essex, 100-117.

[20] Oyenuga, V.A. (1968) Nigerian Foods and Feeding-Stuffs. Their Chemistry and Nutritive Value. Ibadan University Press, Ibadan.

[21] Wardlaw, G.M. (2004) Perspectives in Nutrition. 6th Edition, McGraw Hill Companies, New York.

[22] Food and Nutrition Board (2004) Dietary Reference Intakes for Vitamins. National Academy of Sciences, Washington DC.

[23] Mamiro, P.S., Mwanri, A.W., Mongi, R.J., Chivaghula, T.J., Nyagaya, M. and Ntwenya (2017) Effect of Cooking on Tannin and Phytate Content in Different Bean (Phaseolus vulgaris) Varieties Grown in Tanzania. African Journal of Biotechnology, 16, 1186-1191. https://doi.org/10.5897/AJB2016.15657

[24] Anchan, C. (2010) Proximate Composition and Functional Properties of Pra (Elateriospermun tapas Blume) Seed Flour. Department of Food Science and Technology, School of Science, Bangkok.

[25] Oladele, A.K. and Aina, J.C. (2007) Chemical Composition and Functional Properties of Flour Produced from Two Varieties of Tiger Nut (Cyperus esculentus). African Journal of Biotechnology, 3, 2473-2476. https://doi.org/10.5897/AJB2007.000-2391

[26] Akubor, P.I. and Baclifu (2004) Chemical Composition, Functional Properties and Baking Potential of African Breadfruit Kernel and Wheat Flour Blends. International Journal of Food Science and Technology, 39, 223-229. https://doi.org/10.1046/j.0950-5423.2003.00768.x 